\title{
APLIKASI MASLAHAT DENGAN PENERAPAN DALIL SYARAK KIAS DALAM KONSTRUKSI HUKUM ISLAM INDONESIA
}

\author{
Budiarti \\ Universitas Islam Negeri Alauddin Makassar \\ Email: budiartirahman@uin-alauddin.ac.id
}

\begin{abstract}
Abstrak
Kajian ini bertujuan untuk mengeksplorasi aplikasi maslahat melalui penerapan dalil syarak sekunder kias dalam konstruksi hukum Islam di Indonesia yang diproduksi melalui proses ijmak ulama, yaitu Kompilasi Hukum Islam (KHI). Produk hukum Islam tersebut, diakui eksistensinya sebagai hukum mandiri dalam negara hukum Pancasila. Materi muatan dalam KHI merupakan hasil aplikasi tujuan hukum Islam dengan orientasi maslahat melalui penerapan dalil syarak kias yang diformulasikan oleh Imam Syafii sebagai peletak dasar teori dalam hukum Islam. Aplikasi maslahat melalui penerapan dalil syarak kias, menghasilkan perumusan hukum tentang wali nikah, mahar yang cacat, dan nafkah mut'ah (pesangon) bagi istri yang dicerai seperti termaktub dalam KHI. Implikasi penelitian menegaskan bahwa penting mengoptimalkan metodologi dalam melakukan penggalian hukum yang berorientasi kepada kemaslahatan pada satu sisi dan tetap mempertimbangkan nas syarak pada sisi lain, sebagaimana dibuktikan efektifitasnya dalam penerapan dalil syarak kias pada materi KHI.
\end{abstract}

Kata Kunci:Aplikasi Maslahat, Dalil Syarak Kias, Hukum Islam Indonesia.

\begin{abstract}
This study aims to explore the application of maslahat through the application of a secondary, compact syllable proposition in the construction of Islamic law in Indonesia which is produced through the ijmak ulama process, namely the Compilation of Islamic Law (KHI). The product of Islamic law, its existence is recognized as an independent law in the state of Pancasila law. The content material in KHI is the result of the application of the objectives of Islamic law with maslah orientation through the application of the caustic syllable propositions formulated by Imam Syafii as the foundation of the theoretical basis in Islamic law. Maslahat applications through the application of the proposition shari'ah kias, resulting in the formulation of laws regarding marriage guardians, disabled brides, and livelihood mut'ah (severance) for divorced wives as stated in KHI. The research implication confirms that it is important to optimize the methodology in conducting legal excavations oriented to benefit on the one hand and still consider the shari'a on the other side, as evidenced by its effectiveness in applying the syllabic propositions to KHI material.
\end{abstract}

Keywords: Application interests, Manual measurement, Indonesian Islamic Law 


\section{Pendahuluan}

Hukum Islam merupakan salah satu tradisi hukum di dunia yang dapat dikaji secara terbuka oleh para pengkaji ilmu hukum dengan berbagai macam pendekatan keilmuan. Namun tradisi hukum ini memiliki ciri khas yang menjadi karakter tersendiri. Tradisi hukum yang dikenal di dunia sampai sekarang ini, setidaknya terdiri dari tradisi hukum Islamic law, tradisi hukum Eropa Kontinental, tradisi hukum Anglo Saxon, tradisi hukum Customanary law, dan tradisi hukum Socialis law.

Hukum Islam sebagai tradisi Islamic Law memiliki karakter sebagai ciri khas yang membedakan dengan tradisi hukum yang lain, yaitu bersifat divine law dengan karakteristik top down. Karena itu, untuk mempelajarinya haruslah terlebih dahulu mengetahui sumber utama hukum Islam, yaitu Alquran dan sunah. Para pengkaji hukum Islam dituntut untuk memahami secara mendalam tentang makna dan kandungan hukum yang terdapat dalam Alquran dan hadis sebagai sumber hukum yang manshush.

Pemahaman terhadap kedua sumber hukum tersebut, ada yang tekstual (nas) dan ada yang kontekstual (al-waqi'). Hal tersebut sangat terkait dengan kondisi dewasa ini dengan munculnya beberapa persoalan yang tidak dapat lagi ditemukan secara langsung padanya dalam Alquran dan hadis, para yuris melakukan penalaran hukum melalui ijtihad. ${ }^{1}$

Seorang yuris dalam melakukan ijtihad harus memfokuskan diri pada kandungan universal suatu lafaz. Artinya, problematik apapun yang hadir di tengah kehidupan manusia pada era industri sekarang ini, tidaklah mungkin untuk diberinya suatu nilai kesyariahan tanpa dihubungkan dengan suatu lafaz.

Terdapat beberapa aliran mazhab golongan dalam sejarah perkembangan hukum Islam, di antaranya aliran mazhab yang melakukan penalaran hukum degan melakukan pemahaman murni terhadap lafadz secara apa adanya. Karena itu, apa yang tampak pada nas dipahami secara tekstual. Aliran ini dikenal dengan alzahiriyah. Pemberian nama al-Zahiriyah karena dinisbatkan pada Daud al-Zahiri. Paham ini dalam melakukan istinbath hukum memfokuskan diri pada pemahaman makna nas semata tanpa menggunakan kias (analogi), karena apa yang ada dalam nas tersebut sudah jelas. ${ }^{2}$

\footnotetext{
${ }^{1}$ Hamka Haq, Falsafah Ushul Fikih (Cet II; Makassar: Yayasan Ahkam, 2000), h. 203.

${ }^{2}$ al-Syatiby, al-Muwafaqat fi Ushul al-Fikih, Juz II; (Mesir: Dar al-Fikr al-Araby, t.t.h), h. 392.
} 
Aliran mazhab ini berpandangan bahwa Alquran dan sunah telah mencakup hukum-hukum syariat, baik yang mengandung norma wajib maupun norma haram. Upaya penalaran hukum harus dirumuskan sebagaimana yang tercantum dalam nas Alquran dan sunah. Metode yang sering dipergunakannya adalah melakukan pencarian makna melalui kaidah kebahasaan. Walaupun demikian, aliran mazhab ini dikenal sebagai aliran yang mengembangkan pemikiran hukum dengan pendekatan kebahasaan. $^{3}$

Ibn Hazm sebagai salah satu pengikut aliran mazhab ini menegaskan perlunya penggunaan akal dalam memberikan argumentasi syari'ah. Namun dalam memberikan argumentasi hukum, akal harus berlandaskan pada Alquran sebagai syarat sahnya suatu argumentasi hukum. Ibn Hazm menolak orang yang memfungsikan akal sebagai instrumen utama untuk menetapkan wajib dan haramnya sesuatu, sebab akal menurutnya hanya diberi kewenangan untuk memahami perintah larangan Allah dan hukum untuk menetapkan wajib dan haram. ${ }^{4}$

Ciri khas aliran Mazhab Dzhahiri dalam melakukan istinbath hukum adalah tidak mempergunakannya metode kias. Penolakan dalam menggunakan kias sebagai salah satu metode dalam melakukan penalaran hukum melalui ijtihad, seperti yang diuraikan Abu Zahra, yaitu; Pertama, bahwa Allah sebagai syari' telah menegaskan hukum-hukumnya berupa wajib, haram, sunat, dan makruh. Selain dari hukum tersebut dengan sendirinya menjadi mubah sebagaimana terdapat dalam QS. Al-Baqarah/2: Apabila segenap hukum itu telah disebutkan dalam dzahir nash, baik dalam bentuk umum maupun khusus, maka dengan sendirinya tak ada lagi qiyas; Kedua, orang yang melakukan kias memandang bahwa dalam hukum syarak tidak semua ada nasnya. Argumen ini menolak kesempurnaan syariat yang ditegaskan dalam Q.S. Al-Maidah/5: 3; Ketiga, kias itu didasarkan atas adanya suatu ilat, yakni suatu unsur persamaan antara pokok dan cabang dari suatu masalah. Bagi Zahiriyah, ilat seperti itu mestilah bersandar pada dalil, dan jika memang ada dalilnya maka tidak lagi dinamai kias; Keempat, bahwa terdapat beberapa ayat yang menunjukkan ketidakbolehan melakukan kias seperti firman Allah Swt. dalam Q.S. Al-Hujurat/49 : 1 dan Q.S. al-An'am/ 6: 38.

\footnotetext{
${ }^{3}$ Hamka Haq, loc. cit.

${ }^{4}$ Ibn Hazm, Al-Ahkam fi Ushul al-Ahkam, Juz I (Beirut: Dar al Afaq al-Jadidah, t.th), h. 16.
}

${ }^{5} \mathrm{Abu}$ Zahra, Ushul al-Fikih (Mesir: Dar al-Fikr al-Araby, t. th), 224-226. Argumen ini juga dimuat dalam Hamka Haq, op. cit., h. 207-210. 
Kajian literatur yang penulis telusuri berkaitan dengan penerapan dalil syarak kias, terdapat tulisan yang menyinggung dalam kajiannya. Di antaranya, Yusna Zaidah $(2017)^{6}$, ia menguraikan istinbath hukum melalui penerapan metode kausasi dengan melakukan interpretasi dengan mencari ilat (kias). Namun hanya sekadar mendeskripsikan tentang metode penemuan hukum (thuruq al-istinbath) yang telah ditawarkan oleh para yuris terdahulu sehingga fokusnya berbeda dengan kajian ini.

Demikian halnya dengan Edi Gunawan $(2015)^{7}$, ia mengkaji tentang pembaruan hukum Islam dalam Kompilasi Hukum Islam dengan fokus kajian materi pembaruan hukum Islam melalui proses qanun (positivisasi). Namun tidak menguraikan secara metodologis bagaimana proses penerapan dalil syarak sekunder seperti metode kias yang banyak mempengaruhi hasil substansi dalam produk KHI. Karena itu, kajian ini berbeda dengan kajian sebelumnya karena fokusnya ada pada analisis bagaimana aplikasi maslahat penerapan dalil syarak kias dalam mengkonstruksi produk hukum Islam di Indonesia sebagai pembaruan dalam hukum Islam.

Berkaitan dengan hal tersebut, maka metode aplikasi penerapan dalil syarak kias dalam melakukan penalaran hukum tampak signifikan untuk kemudian mengkaji bagaimana relevansinya pembaruan hukum Islam di Indonesia dalam materi hukum yang terdapat dalam Kompilasi Hukum Islam (KHI).

Pertimbangan penulis mengkaji berdasarkan rumusan metode Imam Syafii ini karena karena Mazhab Syafii merupakan mazhab yang paling populer dalam tradisi masyarakat Islam di Indonesia ${ }^{8}$. Seperti yang diungkapkan oleh Ibnu Batutah sebagaimana ditulis oleh Ayang U. Yakin bahwa pada masa abad ke-14, umat Islam di Samudaera Pasai telah mengikuti mazhab Syafi'i. Bahkan Sultan sebagai penguasa mengajarkan fikih Mazhab Syafi' i. ${ }^{9}$ Maka dapat dipastikan bahwa mazhab Syafi' 'i masuk seiring dengan masuknya Islam di Nusantara ketika itu, mengingat bahwa Nusantara merupakan jalur penting perdagangan internasional antara Timur dan Barat.

6 Yusna Zaidah,. "Model Hukum Islam: Suatu Konsep Metode Penemuan Hukum melalui Pendekatan Ushuliyyah." Syariah: Jurnal Hukum dan Pemikiran 17, no. 2 (2018): 143-159.

${ }^{7}$ Edi Gunawan,. "Pembaruan Hukum Islam dalam Kompilasi Hukum Islam." HUNAFA: Jurnal Studia Islamika 12, no. 2 (2015): 281-305.

8 Zukhdi, Muhammad. "DINAMIKA PERBEDAAN MADZHAB DALAM ISLAM (Studi terhadap Pengamalan Madzhab di Aceh)." Jurnal Ilmiah Islam Futura 17, no. 1 (2017): 121-149.

${ }^{9}$ Ayang Utriza Yakin, Sejarah Hukum Islam; Abad XIV-XIX M (Jakarta: Kencana, 2016), h. 1617. 


\section{Kajian Hukum Islam dan Kompilasi Hukum Islam (KHI) di Indonesia}

Pembicaraan syariat Islam mencakup ruang lingkup yang bersifat menyeluruh, baik berdimensi nilai-nilai Ilahi, dan nilai-nilai Insani. Ruang lingkup ini tercakup dalam masalah-masalah akidah, ibadah, dan Muamalat serta akhlak atau tasawuf. Sejalan dengan itu, tampaknya terjadi mata rantai antara fikih dan syariat. Oleh karena itulah, dapat dipahami bahwa syariat adalah konsep substansial dari seluruh ajaran Islam, meliputi aspek keyakinan, moral, dan hukum, sementara fikih merupakan upaya untuk memahami ajaran Islam tersebut.

Syariat Islam merupakan firman Allah yang ditujukan kepada orang mukalaf yaitu orang-orang yang sudah mengerti tentang bertanggung jawab hukum, berupa perintah, larangan atau kewenangan memilih yang bersangkutan dengan tindakannya. ${ }^{10}$ Pengertian syariat Islam yang lazim dianut menurut Mahmud Syaltut adalah peraturan-peraturan yang diciptakan Allah atau yang diciptakan pokok-pokoknya, sedangkan manusia berpegang kepadanya dalam hubungannya dengan Tuhan dan dengan saudaranya sesama manusia, beserta hubungannya dengan alam seluruhnya dan hubungannya dengan kehidupan. ${ }^{11}$

Ibrahim Hosen mendefinisikan hukum Islam sebagai seperangkat aturan yang ditetapkan secara langsung dan tegas oleh Allah swt. atau ditetapkan pokok-pokoknya untuk mengatur hubungan manusia dengan Allah, manusia dengan sesamanya dan manusia dengan alam semesta ${ }^{12}$

Terkait dengan paradigma ini, Ahmad Rofiq mencoba mengemukakan pengertian hukum Islam di Indonesia sebagai peraturan yang diambil dari wahyu dan diformulasikan dalam keempat produk pemikiran hukum, yaitu : Fikih, Fatwa Ulama, Keputusan Pengadilan (Yurisprudensi) dan Undang-Undang (Qanun) yang dipedomani dan diberlakukan bagi umat Islam di Indonesia ${ }^{13}$

${ }^{10}$ Subhi Mahmassāni, Falsafah al-Tasyri'I fi al-Islām, (Cet. II; Bairūt: Dār al-Kasysyāf,1952), h. 11. Lihat juga Umar Shihab, al-Qur'an dan Kekenyalan Hukum (Cet. I; Semarang : PT. Dina Utama Semarang, 1993), h. 30

${ }^{11}$ Mahmud Syaltut, al-Islām Aqīiah wa Syarī'ah (Qāhirah, Dār al-Qalam, t.th) h. 12.

12 Ibrahim Hosen, Fungsi dan Karakteristik Hukum Islam dalam Kehidupan Umat Islam dalam Amrullah Ahmad, Dimensi Hukum Islam dalam Sistem Hukum Nasional (Cet. I; Jakarta : Gema Insani Press, 1996), h. 86-87.

h. 6 .

${ }^{13}$ Ahmad Rafiq, Hukum Islam di Indonesia (Cet. II; Jakarta : PT. Raja Grafindo Persada, 1997) 
Peristilahan hukum Islam dan literatur berbahasa Arab, kata yang digunakan adalah fikih dan syariat atau hukum syarak, syariat atau hukum syarak secara sederhana diartikan dengan "Seperangkat aturan dasar tentang tingkah laku manusia yang ditetapkan secara umum dan dinyatakan secara langsung oleh Allah Swt. dan Rasul-Nya”. Adapun fikih secara sederhana diartikan "hasil penalaran pakar hukum (mujtahid) atas hukum syarak yang dirumuskan dalam bentuk aturan terperinci”. Sedangkan menurut terminologi "hukum Islam" merupakan gabungan dari syariat Islam dan fikih secara sederhana adalah "Seperangkat peraturan berdasarkan wahyu Allah dan Sunah Rasul tentang tingkah laku manusia mukalaf yang diakui berlaku dan mengikat untuk semua orang yang beragama Islam”. Proses pengolahan dari hukum Syarak menjadi rumusan fikih. ${ }^{14}$

Untuk memahami pengertian hukum Islam perlu diketahui pengertian hukum secara umum, secara sederhana, yaitu menurut Amir Syarifuddin bahwa:

"Seperangkat peraturan tentang tingkah laku manusia yang diakui sekelompok masyarakat; disusun orang-orang yang diberi wewenang oleh masyarakat itu; berlaku dan mengikat untuk seluruh anggotanya"15.

Hukum Islam merupakan istilah khas di Indonesia, sebagai terjemahan dari alFiqh al-Islamy atau dalam keadaan konteks tertentu dari al-Syari'ah al-Islamy. Istilah ini dalam wacana ahli hukum Barat disebut Islamic Law. Dalam Alquran dan sunah, Istilah al-Hukm al-Islam tidak ditemukan. Namun, yang digunakan adalah kata syariat Islam.

Eksistensi Hukum Islam di Indonesia seiring dengan hadirnya Negara Kesatuan Republik Indonesia, tidak dapat dilepaskan dari konstitusi UUD 1945. Perdebatan oleh para pendiri bangsa ketika hendak mendeklarasikan suatu negara yang merdeka berlangsung dengan penuh dinamika yang saling tarik menarik antara golongan nasionalis sekular dan golongan nasionalis islamis.

Kesepakatan atas dasar musyawarah mufakat dan pertimbangan persatuan atas negara yang majemuk, akhirnya para pendiri bangsa menyepakati tujuh kata pada sila pertama yang tercantum dalam Piagam Jakarta 22 juni 1945, direvisi menjadi Ketuhanan Yang Maha Esa. Penjabaran berikutnya dituangkan dalam pasal 29 : (1) Negara berdasar atas Ketuhanan Yang Maha Esa, dan (2) Negara menjamin kemerdekaan tiap-tiap penduduk untuk memeluk agamanya masing-masing dan untuk beribadah menurut agamanya dan kepercayaannya itu.

${ }^{14}$ Amir Syarifuddin, Meretas Kebekuan Ijtihad: Isu-Isu Penting Hukum Islam Kontemporer di Indonesia (Cet. I; Jakarta : Ciputat Press, 2002), h. 6.

${ }^{15}$ Amir Syarifuddin, Ushul Fiqh (Jakarta : Logos, 1997), h. 5 
Selain itu, secara institusional, lembaga Peradilan Agama yang telah berumur panjang, sepanjang Islam tumbuh dan berkembang di Indonesia, menjadi bagian terpenting dalam perjalanan sejarah Hukum Islam di Indonesia. Secara khusus, pemerintah melalui PP No. 5/SD/1946 bahwa pembinaan peradilan agama diserahkan dari kementerian Kehakiman kepada Kementerian Agama. Tahun 1948 melalui UU No. 19/1948, ada usaha-usaha menarik kembali pengalihan tersebut, dengan bentuk pengolahan peradilan agama ke dalam peradilan umum. Namun karena hal ini tidak sejalan dengan kesadaran hukum masyarakat, UU No. 19 ini tidak pernah dinyatakan berlaku. ${ }^{16}$

Dikeluarkannya UU Darurat No. 1 Tahun 1951, peradilan agama tetap berjalan sebagaimana sebelumnya. Tahun 1957 melalui PP No. 45, pemerintah membentuk peradilan Agama di luar Jawa-Madura dan Kalimantan Selatan. Jadi praktis hingga tahun 1957 masih berlaku tiga tiga peraturan perundang-undangan yang mengatur satu lembaga, yakni Peradilan Agama, meskipun namanya berlainan, yaitu :

1. Staatblad 1882 No. 152 jo. Stbl. 1937 No. 116 dan 610, yang mengatur Peradilan Agama di Jawa dan Madura.

2. Stbl. 1937 No. 638 dan 639 yang mengatur Peradilan Agama di Kalimantan Selatan.

3. Peraturan pemerintah No. 45 tahun 1957 yang mengatur Peradilan Agama di luar Jawa-Madura dan Kalimantan Selatan

Satu tahun berikutnya, tepatnya 1958 mulai dibentuk Pengadilan Agama hingga sekarang di hampir setiap Kabupaten/Kotamadya dan Pengadilan Tinggi Agama. Sampai sekarang di seluruh Indonesia tercatat ada 303 PA dan 18 PTA. Melalui Undang-Undang Nomor 14 Tahun 1970 tentang ketentuan-ketentuan pokok kekuasaan kehakiman, pasal 10 menyatakan bahwa Kekuasaan Kehakiman di Negara Republik Indonesia dilakukan oleh Pengadilan dalam lingkungan Peradilan Umum, Peradilan agama, Peradilan Militer dan Peradilan Tata Usaha Negara.

Berdasarkan amanat pasal 10 tersebut, empat tahun kemudian lahir UndangUndang Nomor 1 Tahun 1974 tentang perkawinan. Sebagai kodifikasi dan unifikasi Hukum perkawinan di Indonesia, yang berlaku untuk semua warga negara, yang praktis terdapat keragaman hukum di dalamnya. Dapat dikatakan sejak itulah Hukum Perkawinan Islam mendapat legitimasi yuridis untuk diterapkan bagi masyarakat

\footnotetext{
${ }^{16}$ Munawir Syadzali, “ Landasan Pemikiran Politik Hukum Islam dalam Rangka Mennentukan Peradilan Agamadi Indonesia," dalam Tjun Surjanan (ed), Hukum Islam di Indonesia Pemikiran dan Praktek (Bandung: Rosda Karya, 1991, h.
} 
pemeluknya. Ini dapat dilihat misalnya dalam penjelasan umumnya angka 3 yaitu sebagai berikut :

“...Sesuai dengan landasan falsafah Pancasila dan Undang-Undang Dasar 1945, maka Undang-Undang ini di satu pihak harus dapat mewujudkan prinsip-prinsip yang terkandung dalam Pancasila dan Undang-Undang Dasar 1945. sedangkan di lain pihak harus dapat pula menampung segala kenyataan yang hidup dalam masyarakat dewasa ini, Undang-Undang Perkawinan ini telah menampung di dalamnya unsur-unsur dan ketentuan Hukum Agama dan Kepercayaannya itu dari yang bersangkutan." 17

Keinginan masyarakat muslim untuk menindaklanjuti Undang-Undang No. 14 Tahun 1970 sebenarnya telah dilakukan sebelum kelahiran Undang-Undang Perkawinan. Namun, karena berbagai hal Undang-Undang Peradilan Agama baru dapat disahkan setelah perjuangan berlangsung selama 17 tahun. Dengan amanat Presiden RI No. R06/PU/XII/1988 tanggal 3 Desember 1988 pemerintah menyampaikan Rancangan Undang-Undang (RUU) tentang Peradilan Agama ke DPR. Tanggal 28 Januari 1989 Menteri Agama atas nama Pemerintah RI menyampaikan keterangan atas RUU tersebut dalam sidang paripurna DPR-RI.

RUU Peradilan agama sendiri telah disiapkan kembali tahun 1982 setelah diangkat Tim Inter departemen -sebagai kesepakatan antara Ketua Mahkamah agung, Menteri Agama, dan Menteri Kehakiman- yang anggota-anggotanya terdiri dari; Mahkamah Agung, Departemen Kehakiman, Departemen Agama, Perguruan Tinggi Umum (Universitas Indonesia), Fakultas Syari’ah IAIN Syarif Hidayatullah Jakarta.

Tim tersebut bekerja atas dasar izin prakarsa dari Presiden melalui Surat Menteri Sekretaris Negara RI No. B-2736/M. Sesneg/9/1983 tanggal 13 September 1983 dan No.R.11/Sesneg /2/1984 tanggal 29 Pebruari 1984.Akhirnya setelah melalui perdebatan panjang dan alot, tanggal 29 Desember 1989 RUU tersebut disahkan menjadi UU Nomor 7 tahun 1989 Nomor 49 yang kelak dikenal dengan Undang-Undang Peradilan Agama.

\section{Penerapan Dalil Syarak Kias dalam Istinbath Hukum}

Istinbat secara lughawi adalah dua kata yang tergabung dalam struktur bahasa Arab sebagai mudhaf wa mudhafun ilaih (استتباط الحكم) kata kecara

\footnotetext{
${ }^{17}$ Undang-Undang Perkawinan, Semarang: Beringin Jaya, t.th), h. 26
} 
etimologi adalah hal mengeluarkan. ${ }^{18}$ Sedang kata الحكم berarti hukuman atau peraturan. ${ }^{19}$ Jadi secara bahasa استتباط الحكم adalah mengeluarkan hukum atau putusan.

Sedangkan secara terminologi, menurut Abu Zahrah, metode istinbat hukum (dalam term Ushul al-fiqh familiar dengan istilah Thuruq al-istinbat al-hukm) adalah metode penggalian hukum dari nas-nas, yaitu Alquran dan hadis. Metode ini terbagi dua yaitu metode maknawiyah dan metode lafdziyah. Metode maknawiyah adalah metode istinbat yang mengambil dalil yang tidak terdapat dalam nas-nas Alqur'an dan hadis seperti qiyas, istihsan, maslahah al-mursalah dan sebagainya. Adapun metode lafdziyah adalah metode istinbat melalui makna-makna dari lafadz yang meliputi 'am, khas, dan sebagainya. ${ }^{20}$

Thaha Jabir Fayyadh al-‘Alwani memberikan catatan tentang langkah-langkah dalam melakukan istinbath hukum, yaitu:

“...Dasar pokok hukum (fikih) adalah Alqur'an dan Sunnah. Jika dalil tidak ditemukan dalam keduanya. Kita melakukan qiyas terhadap keduanya. Jika ada sebuah hadis sampai kepada Rasulullah dan isnadnya sahih, maka itulah yang dipegang. Ijmak lebih besar (Argumentatif) dibanding khabar ahad. Tahap pertama dalam memahami hadis adalah melihat makna zahirnya. Jika makna hadis menunjukkan makna ganda, maka yang lebih dekat dengan makna zhahirnya lebih diutamakan untuk dijadikan pegangan. Jika ada beberapa hadis yang muncul dalam satu tema yang sama dan maknanya berbeda, maka yang dipegang aalah hadis yang sanadnya benar-benar sahih. Jika ada hadis yang munqathi' (mursal), maka tidak boleh dipegang kecuali hadis mursal ibn Musayyab. Ashl tidak boleh diqiyaskan pada ashl. Dalam masalah yang prinsipil (ashl) tidak boleh sampai menimbulkan pertanyaan "kenapa" dan "bagaimana?" kalau untuk hal-hal yang bersifat furu' (cabang) boleh menimbulkan pertanyaan "kenapa?" jika suatu furu' sahih proses qiyasnya, maka boleh dijadikan hujjah. ${ }^{21}$

Langkah yang lebih rinci beraitan dengan langkah dalam melakukan istinbath hukum seperti dikemukakan Imam Syafii dalam al-Risalah:

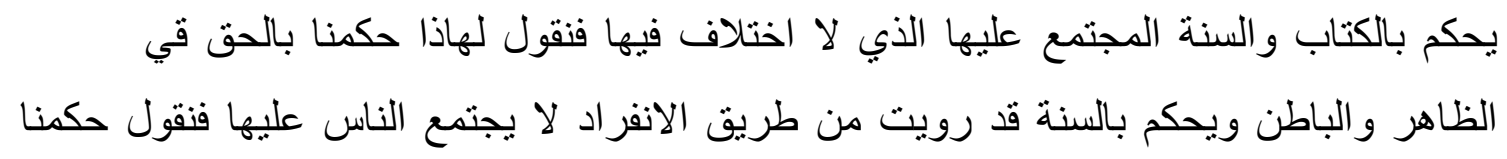

${ }^{18}$ Mahmud Yunus, Kamus Arab Indonesia (Cet. VII; Jakarta: Hida Karya Agung, 1990), h. 437.

${ }^{19}$ Ibid., h. 107.

${ }^{20}$ Muhammad Abu Zahrah, Ushul al-Fiqh (Mesir: Dar al-Fkir al-Araby, t. th), h. 115-116.

${ }^{21}$ Thaha Jabir Fayyadh al-'Alwani, Adab al-Ikhtilaf fi al-Islam, diterjemahkan oleh Ija Suntana dengan judul, Etika berpendapat dalamIslam (Cet.I; Bandung: Pustaka Hidayah, 2001), h. 108-109. 
بالحق في الظاهر لانه قد يمكن الغلط فيمن روي الحديث ونحكم بالاجماع ثم بالقايس و هو اضعف من هاذا ولكنها منلزة الضرورة لانه لا يحل القياس. والخبر موجود كما يكون التيمم طهارة قي السفر عند الاعواز من الماء...وكذاللك يكون ما بعد السنة حجة اذا اعوز من السنة. 22

Artinya:

Hukum ditetapkan dengan Alquran dan al-Sunnah yang telah disepakati tanpa khilaf. Dalam hal ini kita mengatakan, "kita telah menghukum dengan benar pada zhahir dan bathin." Dapat juga ditetapkan berdasarkan Sunnah yang diriwayatkan melalui orang per orang. Jika tidak mendapatkan kesepakatan, maka kita mengatakan, "kita menghukum dengan benar secara zhahir, walaupun masih mungkin terdapat kesalahan pada perawi hadis itu." Selain itu, kita dapat pula menetapkan hukum berdasarkan ijmak, kemudian berdasarkan qiyas, tetapi qiyas itu lebih lemah adanya, namun (tindakan tersebut harus diambil mengingat bahwa) ini adalah keadaann darurat. Qiyas tidak dibenarkan selama ada sunnah, seperti halnya tayammum hanya sah sebagai thaharah, dalam perjalanan, bila air tidak ditemukan. Demikianlah dalil berikutnya hanya digunakan sebagai hujjah bila Sunnah tidak ditemukan.

Pada bagian lain ia mengatakan:

\section{كل ما نزل بمسلم فقيه حكم اوعلي سبيل الحق فيه دلالة موجودة وعليه اذا كان فيه حكم لازماتباعه وا ذا لم يكن فيه بعينه طلب الدلالاة علي سبيل الحق فيه بالاجتحهاد القياس.23}

\section{Artinya:}

Setiap peristiwa yang terjadi atas orang muslim telah ada hukumnya yang tetap atau terdapat petunjuk kepada kebenaran mengenainya. Bila hukumnya telah pasti, maka ia wajib mengikutiya; dan bila hukumnya belum pasti, ia harus mencari petunjuk kepada kebenaran dengan melakukan ijtihad. Ijtihad itu ialah qiyas.

Di dalam kitab al-Umm, Imam Syafii mengatakan:

$$
\begin{aligned}
& \text { و العلم طبقات شتي. الاولي الكتاب و السنة. اذا ثبتت السنة ثم الثانية الاجماع فيما ليس فيه كتاب } \\
& \text { و لا سنة و الثالثة ان يقول بعض اصحاب النبي صلي الله عليه وسلم و لا نعلم له مخالفا منهم. }
\end{aligned}
$$

${ }^{22}$ Imam al-Muthalabby Muhammad Idris al-Syafi'i , al-Risalah, (Cet. II; Mesir: Maktabat Dar alTurats, 1989), h. 599-600.

\footnotetext{
${ }^{23}$ Ibid., h. 477.
} 


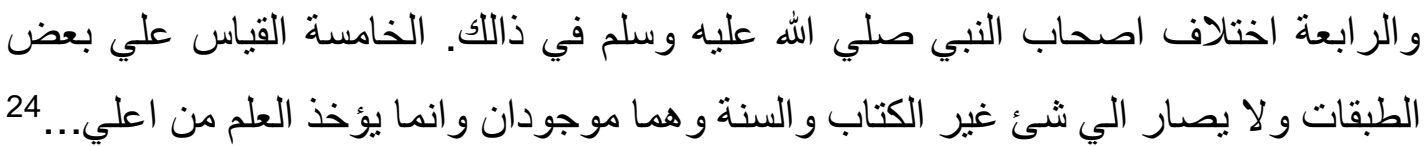

Artinya:

"Ilmu itu ada beberapa tingkatan. Pertama, Alquran dan Sunnah yang sahih. Kedua, ijmak pada masalah yang tidak ditegaskan di dalam Alquran dan Sunnah. Ketiga, perkataan sebagian sahabat yang tidak dibantah oleh sahabat lainnya. Keempat, pendapat sahabat yang diperselisihkan. Kelima , qiyas kepada salah satu tingkatan di atas. Akan tetapi, selama ada kitab dan Sunnah, dalil yang lainnya tidak digunakan, sebab ilmu itu harus diambil dari (sumber) yang paling tingggi..."

Dalam kaitan ini, Imam Haramain, sebagai yang dikutip oleh Lahmuddin Nasution, mengutip bahwa Imam Syafi'i memberikan tatanan ijtihad yang baik yaitu sebagai berikut:

“...Bila ada peristiwa yang mengharuskan mujtahid mencari hukumnya, ia harus memerikasa nas-nas (penegasan) kitab,... bila tidak bertemu , ia beralih kepada nash-nash kabar mutawatir, ... bila tidak bertemu juga, ia beralih kepada nashnash kabar ahad, ...bila juga tidak ditemukan, ia harus mengalihkan pencarian kepada zhawahir (petunjuk lahir) kitab. Akan tetapi, suatu petunjuk zhahirtidak dapat diamalkan sebelum memperhatikan hal-hal yang mungkin men-takhshish (membatasinya) ... kemudian jika tidak ditemukanjuga, ia beralih kepada zhawahir kabar mutawatir, dengan memperhatikan kemungkinan takhshish seperti tadi. Berikutnya bila tidak ada guna, ia beralih kepada kabar ahad. Kalaupun sampai ketingkat ini ia tidak juga menemukan hukum yang dicari itu, ia belum boleh melakukan qiyas, tetapi harus lebih dahulu memperhatikan kaidahkaidah umum (kulliyah) syara' yang mengandung kemaslahatan (al-maslahah alammah). Bila masalahnya tidak terkait dengan maslahat umum, ia harus mencari ijmak. Jika para ulama menegaskan adanya ijmak, ia tidak perlu mencari lebih lanjut. Jika sampai ke sini ia pun belum mendapatkannya, barulah ia berusaha melakukan qiyas. Jika masalahnya tercakup oleh masalah yang telah ada nashnya, tentu penyelesaiannya tidak akan sulit. Bila tidak demikian, ia harus melakukan qiyas dengan memperhatikan kessuaian illah dengan hukum (ikhalah, munasabah, dan isy'ar). Qiyas dapat diamalkansepanjang tidak ada yang menentangnya. Bila dua qiyas ikhalah (yang illah-nya ssuai dengan hukum), bertentangan, maka ia harus mengupayakan tarjih (memilih lebih kuat) ... bila qiyas ikhalah tidak berhasil ditegakkan, barulah ia mencari qiyas syabah, jika itu dianggapnya sebagai hujjah. ${ }^{25}$

Berdasarkan komentar tersebut, maka dapat dikonklusikan bahwa langkahlangkah operasional ijtihad Imam Syafii (thuruq al-istinbath) adalah mencari hukum

\footnotetext{
${ }^{24}$ Al-Imam Abi Abdullah Muhammad bin Idris al-Syafi'I, al-Umm(Beirut: Dar al-Fikr, 1990), h. 280.

${ }^{25}$ Lahmuddin Nasution, Pembaharuan Mazhab Hukum Islam dalam Mazhab Syafi'i (Cet. I; Bandung: PT Remaja Rosdakarya, 2001), h. 162.
} 
secara berturut-turut dari: Pertama, nash-nash Alquran. Kedua, nash-nash Khabar Mutawatir. Ketiga, ijmak ulama terdahulu. Keempat, nas-nash khabar ahad. Kelima, Petunjuk zhahir Alquran dan sunah; Keenam kias.

\section{Aplikasi Maslahat Penerapan Dalil Syarak Kias dalam Kompilasi Hukum Islam}

Proses terbentuknya KHI, Hukum Islam/Fikih Islam yang dipraktekkan (diamalkan) oleh mayoritas masyarakat muslim Indonesia adalah lebih dominan berwarna Syafi'iyyah (Syafi 'i oriented). ${ }^{26}$ Realitas ini tentu saja membuka kemungkinan bahwa warisan intelektual Imam Syafi'i, baik dari segi metode istinbatnya (thuruq istinbat al-hukm), maupun hasil-hasil ijtihadnya (materi fikihnya) untuk terakomodir dalam KHI.

Apabila ditelusuri kitab-kitab yang akan dijadikan rujukan (referensi) Dalam proses pembentukan KHI, maka akan ditemukan bahwa ada 38 kitab fikih yang dikaji oleh ulama-ulama Indonesia yang memiliki otoritas keilmuan di bidang ini. Ke 38 buah kitab fikih ini dikaji oleh tujuh IAIN yang ditunjuk untuk mengkaji dan diminta pendapatnya, beserta argumentasi dan dalil-dalil hukumnya. Perguruan tinggi yang dimaksud, yaitu IAIN Arraniri Banda Aceh, IAIN Syarif Hidayatullah Jakarta, IAIN Antasari Banjarmasin, IAIN Sunan Kalijaga, IAIN Sunan Ampel Surabaya, IAIN Alauddin Ujungpandang, dan IAIN Imam Bonjol Padang. ${ }^{27}$

Dari ke 38 kitab-kitab fikih tersebut di atas, Tiga belas di antaranya adalah kitab-kitab hukum/kitab-kitab fikih yang selama ini diperpegangi Departemenen Agama sebagai buku pedoman/pegangan para hakim. Kitab-kitab yang dimaksud, yaitu $\mathrm{Al}$ -

${ }^{26}$ Bahkan Marzuki Wahid, dalam penelitiannya tentang fikih di Indonesia sejak abad ke 17 sampai abad 20, menyatakan bahwa dinamika fikih Indonesia abad 17 dan 18 adalah dalam wacana Syafi'iyah. Marzuki Wahid mengemukakan 2 alasan. Pertama, proses Islamisasi di Indonesia sejak abad ke 12 dan ke 13 merupakan saat-saat di mana perkembangan hukum Islam berada dalam masa krisis dengan penutupan pintu ijtihad sebagai titik terendahnya, walaupun pada fase berikutnya banyak tokoh yang menggugat hal tersebut. Para ahli tidak lagi berani berpikir sebebas dan sekreatif mungkin, tetapi lebih disibukkan oleh berbagai aktivitas pemikiran untuk mendukung mazhabnya masing-masing. Kedua secara kebetulan para "aktifis" yang melancarkan proses islamisasi di Indonesia sebagaimana disinyalir oleh para sejarawan, adalah mereka yang bermazhab Syafi'i, walaupun pada perkembangan berikutnya tidak semua umat Islam Indonesia menyandarkan perilaku keagamaannya pada kerangka pemikiran fikih Imam Asy-Syafi'i, terutama pada awal abad ke 20 ketika gerakan pembaharuan menemukan moment umnya. Lihat Marzuki Wahid dan Rumadi, Fiqh Mazhab Negara: Kritik atas Politik hukum Islam di Indonesia (Cet. I; Yogyakarta: LKIS, 2001), h. 129. Tesis Marzuki Wahid ini, sejalan dengan penuturan DR. Subhi Mahmassani dalam bukunya The Philosophy of Jurisprudence in Islam. Ia menulis bahwa negara Indonesia, mayoritas penduduknya menganut maChab Syafi'i. Lihat Ali Yafie, Teologi Sosial: Telaah Kritis Persoalan Agama dan Kemanusiaan (Cet. I; Yogyakarta: LKPSM, 1997), h. 133.

${ }^{27}$ Abdurrahman, Kompilasi Hukum Islam di Indonesia (Cet. II; Jakarta: CV Akademika Pressindo, 2001), h.39-41. 
Bajuri, Fath al-Mu'in, Syarqawi 'ala al-Tahrir, Qalyubi/Al-Mahalli, Fath al-Wahab dan syarahnya, Tuhfah, Targib al-Musytaq, Al-Qawanin al-Syar'iyyah (Li Sayyid bin Yahya), Al-Qawanin al-Syar'iyyah(Li sadaqah Dahlan), Syamsuri li a l-Fara'id, Bughyah alMustarsyidin, Kitab al-Fiqh 'ala al-Mazahib al-Arba'ah, Mughni al-Muhtaj. ${ }^{28}$

Dari ke 13 kitab tersebut umumnya adalah kitab-kitab kuno dalam madzhab Syafi'i, kecuali nomor 12 termasuk bersifat komparatif atau perbandingan madzhab. Selain 13 kitab tersebut di atas, yang disebut sebagai kitab-kitab kuno bermazhab Syafi'i, ada lagi satu kitab yang merupakan karya monumental Imam Syafii, yaitu kitab al-Umm. Dengan menelaah kitab-kitab yang dijadikan referensi dalam proses pembentukan KHI tersebut di atas, mengindikasikan adanya relevansi metode istinbat hukum Imam Syafi'i dalam qaul qadim dan qaul jadidnya terhadap KHI. Relevansi yang dimaksud adalah banyaknya kitab-kitab bermazhab Syafii dan juga karya monumental Imam Syafi'i yang dijadikan sebagai referensi dalam melahirkan KHI.

Sementara itu, dalam proses pembentukan KHI, ada lima jalur yang ditempuh dalam melahirkan KHI. Jalur yang dimaksud ini adalah:
a. Pengkajian kitab-kitab fikih
b. Wawancara dengan para ulama
c. Yurispondensi Pengadilan Agama
d. Studi perbandingan hukum dengan negara lain.
e. Loka karya/seminar materi hukum untuk pengadilan agama. ${ }^{29}$

Apabila ditelusuri lebih jauh jalur-jalur yang ditempuh dalam melahirkan KHI secara komprehensif di atas, maka akan ditemukan salah satu mekanisme pengambilan hukum yang relevan dengan metode istinbat hukum Imam Syafii dalam qaul qadim dan qaul jadidnya. Mekanisme yang dimaksud adalah jalur kelima yaitu lokakarya nasional. Lokakarya nasional itu sendiri merupakan implementasi konsensus (ijmak) ulama dan ahli hukum Indonesia dalam konteks era kontemporer. Sebagai hasil ijmak ulama Indonesia, ia wajib diikuti oleh masyarakat muslim Indonesia.

Hierarki proses penggalian hukum Imam Syafii, ijmak menempati posisi yang ketiga setelah Alquran dan Hadis. Bahkan Imam Syafii lebih mendahulukan ijmak daripada khabar Ahad.

\footnotetext{
${ }^{28}$ Abdurrahman, op.cit.., h. 22

${ }^{29}$ Saekan dan Erniati, Sejarah Penyusunan Kompilasi Hukum Islam di Indonesia (Cet. I; Surabaya: Arloka, 1997), h. 26-29.
} 
Olehnya itu, KHI yang lahir dari suatu konsensus ijmak ulama Indonesia dalam konsep penggalian hukum Islam Imam Syafii memiliki status hukum yang sangat kuat. Defenisi ijmak menurut Imam Syafi'i dapat dilihat sebagai berikut:

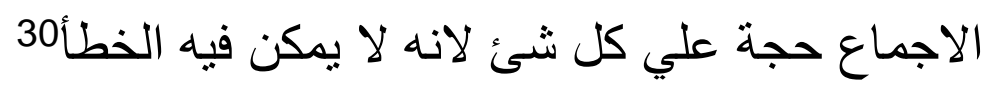

Dari ucapan Imam Syafi'i di atas, Lahamudin Nasution merumuskan bahwa ijmak menurut Imam Syafi'i adalah kesepakatan para ulama (ahl al-ilm) tentang suatu hukum syarak. Ahl al-ilm yang dimaksudkannya adalah para ulama yang dianggap sebagai faqih dan fatwa serta keputusannya diterima oleh penduduk di suatu negeri. ${ }^{31}$ Hal yang juga menarik untuk diperhatikan pada KHI ini adalah setelah melalui suatu konsensus para ulama dan ahli hukum Indonesia, maka ia diperkuat dengan Instruksi Presiden Nomor 1 Tahun 1991 untuk penyebaran KHI.. ${ }^{32}$ hal ini sejalan dengan satu kaidah fikih yang dikembangkan oleh Imam Syafi'i yaitu:

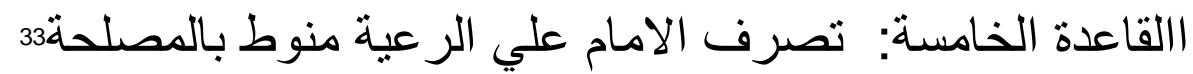

Dengan menyimak kaidah tersebut, maka sepanjang muatan dari produk peraturan perundangan yang dikeluarkan oleh pemerintah Indonesia membawa kebaikan maka ia wajib dipatuhi karena pemerintah merupakan pemimpin yang harus ditaati sebagaiman pesan-pesan universal dalam Alquran. Adapun aplikasi maslahat penerapan dalil syarak kias terhadap materi KHI adalah berkaitan dengan hak wali saudara kandung dan saudara sebapak, mahar yang rusak, mut'ah (pesangon) bagi istri yang dicerai. Tentang ketiga hal tersebut dalam formulasi KHI, dapat dilihat sebagai berikut:

1. Hak wali saudara kandung dan saudara sebapak

Apabila dalam perkawinan terdapat dua orang yang berhak menjadi wali; yang satu saudara kandung dan satu lagi saudara sebapak, siapakah di antara mereka yang lebih berhak menjadi wali?.

Dalam KHI, bagian ketiga tentang wali nikah, Pasal 21, ayat 3 dikemukakan: “Apabila dalam satu kelompok sama derajat kekerabatannya maka yang paling berhak menjadi wali nikah ialah kerabat kandung dari kerabat yang hanya seayah", 34

\footnotetext{
${ }^{30}$ Al-Imam Abi Abdullah Muhammad bin Idris al-Syafi'I, al-Umm, op.cit.., h. 293

${ }^{31}$ Lahmudin Nasution, op.cit.., h. 86

${ }^{32}$ Lihat Abdurahman, h. 50.

${ }^{33}$ Liahat Al-Asybah wa al-Nazhair h. 184

${ }^{34}$ Abdurrahman, op.cit.., h. 81
} 
Dalam qaul qadim, Imam Syafi'i berpendapat bahwa hak perwalian saudara kandung dan saudara sebapak adalah sama (sejajar) karena wali nikah ditentukan berdasarkan nasab laki-laki. Sedangkan dalam qaul jadid, Imam Syafi'i berpendapat bahwa saudara kandung lebih berhak untuk menjadi wali perkawinan atas saudara sebapak karena mereka lebih berhak mendapatkan 'ashabat (harta waris sisa) dalam pembagian harta pusaka. ${ }^{35}$ Baik rumusan dalam qaul qadim maupun dalam qaul jadid tentang kedudukan perwalian saudara kandung dan saudara sebapak, Imam Syafii membangun argumentasinya dengan menerapkan dalil syarak kias.

2. Mahar yang rusak

Dalam KHI, Bab V tentang mahar, pasal 36 ditemukan:

“Apabila mahar hilang sbelum diserahterimakan, mahar itu dapat diganti dengan barang lain yang sama bentuk dan sejenisnya atau dengan barang lain yang sama nilainya atau dengan uang dinilai dengan harga barang mahar yang hilang". ${ }^{36}$

Sementara itu, dalam qaul qadim, Imam Syafii berpendapat bahwa mahar yang rusak sebelum diserahterimakan antara suami-istri harus diganti dengan benda yang serupa, karena harta tersebut belum diterima oleh istri sehingga suami wajib mengganti mahar yang rusak itu, seperti harta yang digashb. Sedangkan dalam qaul jadid, Imam Syafi'I berpendapat bahwa mahar yang rusak sebelum diserahterimakan harus dibayar dengan mahar mitsl karena suami akan sulit untuk mendapatkan gantinya, seperti seorang membeli pakaian yang ternyata pakaian tersebut rusak, maka penjual harus mengembalikan sejumlah uang yang telah diterimanya apabila kesulitan mencari gantinya. Argumentasi Imam Syafii dalam qaul qadim maupun dalam qaul jadid, keduanya dikonstruksi dengan menggunakan dalil syarak kias.

3. Mut'ah (pesangon) bagi istri yang dicerai

Dalam Alquran, Allah Swt. menganjurkan suami yang menceraikan istrinya untuk memberikan mut'ah (pesangon) kepada istri yang dicerai. Allah berfirman :

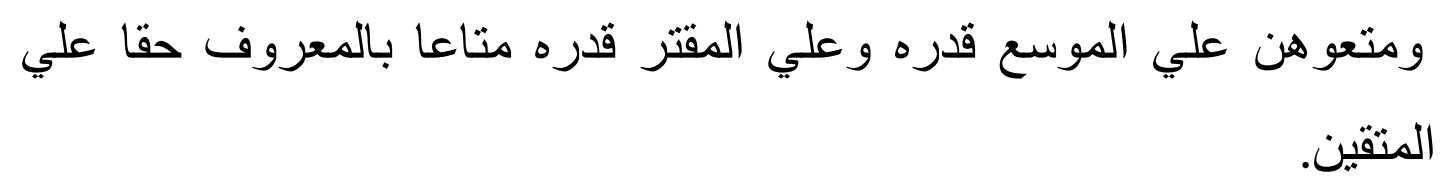

Terjemahannya:

“dan hendaklah kamu memberikan mut'ah (pemberian) kepada mereka. Orang yang mampu menurut kemampuannya dan orang yang miskin menurut

\footnotetext{
${ }^{35}$ Lihat Jaih Mubarok, op.cit.., h. 256-257.

${ }^{36}$ Lihat Abdurrahman, op.cit.., h.121.
} 
kemampuan (pula) yaitu pemberian menurut yang patut. Yang demikian itu merupakan ketentuan bagi orang-orang yang berbuat kebajikan."37

Persoalannya adalah apakah perintah untuk memberikan pesangon tersebut wajib atau tidak?.

Dalam KHI, bagian keempat tentang mut'ah, pasal 158 dan pasal 159 disebutkan :

Pasal 158

Mut'ah wajib diberikan oleh bekas suami dengan syarat-syarat :

a. Belum ditetapkan mahar bagi istri ba'da al-dukhul.

b. Perceraian itu atas kehendak suami.

Pasal 159

Mut'ah sunat diberikan oleh bekas suami tanpa syarat tersebut pada pasal $158 .{ }^{38}$

Sementara itu, dalam qaul qadim, Imam Syafii berpendapat bahwa suami tidak wajib memberikan pesangon kepada istri yang dicerainya, karena istri telah mendapatkan mahar. Sedangkan dalam qaul jadidnya Imam Syafi'i berpendapat bahwa suami wajib memberi pesangon kepada istri yang dicerainya sesuai dengan firman Allah Q.S. al-Ahzab (33): 28 :

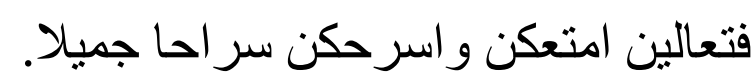

Terjemahnya:

"Maka marilah supaya kuberikan kepadamu mut'ah dan aku ceraikan kamu dengan cara yang baik." 39

Qaul qadim Imam Syafi'i di atas, berdasarkan pada penerapan hukum berdasarkan dalil syarak kias sedangkan dalam qaul jadid argumennya adalah Alquran surat al-Ahzab (33): $28 .{ }^{40}$

Apabila mencermati antara materi KHI dan qaul qadim-qaul jadid Imam Syafi'i tentang hukum memberikan pesangon pada istri yang dicerai, maka terlihat bahwa KHI mengakomodir qaul qadim-qaul jadid Imam Syafi'i. KHI mengemukakan 2 pasal (pasal 158 dan pasal 159) yaitu: Pertama, wajib memberi pesangon dengan dua persyaratan;

\footnotetext{
${ }^{37}$ Departemen Agama R.I, Al-Qur'an dan Terjemahnya, (Surabaya: Surya Cipta Aksara, 1993),
} h. 58 .

\footnotetext{
${ }^{38}$ Abdurahman, op.cit.., h. 152

${ }^{39}$ Departemen Agama RI, op.cit., h. 671.

${ }^{40}$ Jaih Mubarok, op.cit.., h. 268-269.
} 
belum ditetapkan mahar bagi istri $b a^{\prime} d a$ al-dukhul dan perceraian itu atas kehendak suami. Kedua, sunat dengan catatan 2 (dua) syarat tersebut tidak ada.

Hal ini menunjukkan bahwa penerapan dalil syarak kias yang dibangun oleh Imam Syafii memberikan sumbangsih efektif dalam perumusan materi KHI. Ketiga contoh di atas, terlihat metode istinbat Imam Syafi'i dalam qaul qadim dan qaul jadidnya diakomodir dalam proses pembentukan dan materi hukum KHI.

Upaya merasionalisasi dengan melakukan kodifikasi materi hukum hasil penerapan dalil syarak kias sebagaimana terdapat dalam fatwa qaul qadim dan qaul jadid Imam Syafii ke dalam hukum nasional (KHI), menunjukan bahwa metode penerapan dalil syarak kias oleh Imam Syafii dalam qaul qadim dan qaul jadidnya memiliki relevansi yang signifikan dan efektif dalam pembaruan hukum Islam di Indonesia.

\section{Penutup}

Penerapan dalil syarak kias dalam melakukan pengalian hukum yang telah diletakkan dasar teoretisnya oleh Imam Syafii mempunyai sumbangsih secara efektif dalam merespons kebutuhan hukum Islam di Indonesia yang telah dibentuk secara konsensus bentuk kompilasi Hukum Islam (KHI). Aplikasi penerapan dalil syarak kias dapat dilihat materi hukum KHI sebagaimana terdapat dalam 3 pasal yang secara jelas dapat dikatakan merupakan hasil adopsi dari fatwa-fatwa Imam Syafii , yaitu hak wali saudara kandung, mahar yang rusak dan pemberian mut'ah (pesangon) bagi istri yang dicerai. Ketiga pasal tersebut berasal dari argumentasi hukum Syafii dengan menggunakan metode kias.

Implikasi penelitian menegaskan pentingnya mengoptimalkan metodologi dalam melakukan penggalian hukum yang berorientasi kepada kemaslahatan pada satu sisi dan tetap mempertimbangkan nas syarak pada sisi lain, sebagaimana efektifitas penerapan dalil syarak kias dalam materi KHI. Hal tersebut dikarenakan baik dari segi pemahaman, maupun penerapannya senantiasa berorientasi kepada perpaduan antara maslahat dan nas syariat.

\section{DAFTAR PUSTAKA}

Abdurrahman. Kompilasi Hukum Islam di Indonesia. Cet. II; Jakarta: CV Akademika Pressindo, 2001.

Alwani, Thaha Jabir Fayyadh al-`. Adab al-Ikhtilaf fi al-Islam, diterjemahkan oleh Ija 
Suntana dengan judul, Etika berpendapat dalamIslam. Cet.I; Bandung: Pustaka Hidayah, 2001.

Basyir, Ahmad Azhar. "Hukum Islam di Indonesia dari Masa ke Masa." UNISIA 16 (2016): 9-13.

Gunawan, Edi. "Pembaruan Hukum Islam dalam Kompilasi Hukum Islam." HUNAFA: Jurnal Studia Islamika 12, no. 2 (2015): 281-305.

Haq, Hamka. Falsafah Ushul Fikih. Cet II; Makassar: Yayasan Ahkam, 2000

Hazm, Ibn. Al-Ahkam fi Ushul al-Ahkam, Juz I. Beirut: Dar al Afaq al-Jadidah, t.th

Hosen, Ibrahim. Fungsi dan Karakteristik Hukum Islam dalam Kehidupan Umat Islam dalam Amrullah Ahmad, Dimensi Hukum Islam dalam Sistem Hukum Nasional. Cet. I; Jakarta : Gema Insani Press, 1996.

Mahmassāni, Subhi. Falsafah al-Tasyri'I fi al-Islām. Cet. II; Bairūt: Dār alKasysyāf, $1 \dot{9} 52$.

Nasution, Lahmuddin. Pembaharuan Mazhab Hukum Islam dalam Mazhab Syafi'i. Cet. I; Bandung: PT Remaja Rosdakarya, 2001.

Rafiq, Ahmad. Hukum Islam di Indonesia. Cet. II; Jakarta : PT. Raja Grafindo Persada, 1997.

Saekan dan Erniati. Sejarah Penyusunan Kompilasi Hukum Islam di Indonesia. Cet. I; Surabaya: Arloka, 1997.

Shihab, Umar. al-Qur'an dan Kekenyalan Hukum. Cet. I; Semarang : PT. Dina Utama Semarang, 1993.

Syadzali, Munawir. "Landasan Pemikiran Politik Hukum Islam dalam Rangka Mennentukan Peradilan Agamadi Indonesia," dalam Tjun Surjanan (ed), Hukum Islam di Indonesia Pemikiran dan Praktek. Bandung: Rosda Karya, 1991.

Syafi'I, Al-Imam Abi Abdullah Muhammad bin Idris al-. al-Umm. Beirut: Dar al-Fikr, 1990.

Syafi'i, Imam al-Muthalabby Muhammad Idris al-. al-Risalah. Cet. II; Mesir: Maktabat Dar al-Turats, 1989.

Syaltut, Mahmud. al-Islām Aqīiah wa Syarī'ah. Qāhirah, Dār al-Qalam, t.th.

Syarifuddin, Amir. Meretas Kebekuan Ijtihad: Isu-Isu Penting Hukum Islam Kontemporer di Indonesia. Cet. I; Jakarta : Ciputat Press, 2002.

Syarifuddin, Amir. Ushul Fiqh. Jakarta : Logos, 1997.

Syatiby, al-Muwafaqat fi Ushul al-Fikih, Juz II; Mesir: Dar al-Fikr al-Araby, t.t.h

Wahid, Marzuki dan Rumadi. Fiqh Mazhab Negara: Kritik atas Politik hukum Islam di Indonesia. Cet. I; Yogyakarta: LKIS, 2001.

Yakin, Ayang Utriza. Sejarah Hukum Islam; Abad XIV-XIX M. Jakarta: Kencana, 2016.

Yunus, Mahmud . Kamus Arab Indonesia. Cet. VII; Jakarta: Hida Karya Agung, 1990.

Zahra, Abu . Ushul al-Fikih. Mesir: Dar al-Fikr al-Araby, t. Th.

Zahrah, Muhammad Abu. Ushul al-Fiqh. Mesir: Dar al-Fkir al-Araby, t. Th.

Zaidah, Yusna. "Model Hukum Islam: Suatu Konsep Metode Penemuan Hukum melalui Pendekatan Ushuliyyah." Syariah: Jurnal Hukum dan Pemikiran 17, no. 2 (2018): 143-159.

Zukhdi, Muhammad. "Dinamika Perbedaan Madzhab dalam Islam (Studi terhadap Pengamalan Madzhab di Aceh)." Jurnal Ilmiah Islam Futura 17, no. 1 (2017): 121-149. 